\title{
Novel ecosystems in the Anthropocene: a revision of the novel ecosystem concept for pragmatic applications
}

\author{
$\underline{\text { Nathaniel B. Morse }}^{1,2}, \underline{\text { Paul A. Pellissier }}^{1,2}$, Elisabeth N. Cianciola $^{1}, \underline{\text { Richard L. Brereton }}^{1}, \underline{\text { Marleigh M. Sullivan }}^{1}, \underline{\text { Nicholas K. }}$
} $\underline{\text { Shonka }}^{1}, \underline{\text { Tessa B. Wheeler }}^{1}$ and William H. McDowell ${ }^{1}$

\begin{abstract}
Ecologists have developed terminology to distinguish ecosystems based on the degree of human alteration. To this end, ecosystems can be characterized as "novel ecosystems," "impacted ecosystems," or "designed ecosystems," depending on the role of human management in ecosystem development and effects on ecosystem properties. Properly classifying an ecosystem as novel, impacted, or designed has critical implications for its conservation and management, but a broadly applicable definition for a "novel ecosystem" does not exist. We have provided a formal definition of "novel ecosystem" that facilitates its use in practical applications and have described four characteristics of such an ecosystem. A novel ecosystem can be identified by its origins rooted in human agency, the ecological thresholds it has crossed, a significantly altered species composition, and a capacity to sustain itself. Ecosystem classification in the literature has been inconsistent. We have illustrated the application of our definition using multiple case studies representing impacted, designed, and novel ecosystems.
\end{abstract}

Key Words: ecosystem management; novel ecosystem; resilience; restoration; threshold

\section{INTRODUCTION}

Growing awareness that most of Earth's ecosystems are influenced by humans (Vitousek et al. 1997) and recognition that many of the ecosystems resulting from this influence do not resemble their natural precursors have led ecologists to distinguish between ecosystems with degraded structure and functionality and novel ecosystems. Some ecologists have argued that novel ecosystems should be managed differently from degraded ecosystems, valued for the ecosystem services they provide, and not treated as restoration priorities (Hobbs et al. 2006). However, a broadly applicable definition of a novel ecosystem is lacking along with specifics on how novel ecosystems differ from degraded ecosystems.

Since its first use by Chapin and Starfield (1997), the concept of the "novel ecosystem" has gained traction among ecologists who wish to describe ecosystems with biotic and/or abiotic characteristics altered by humans. First used to describe Arctic tundra transitioning to boreal grassland steppe under altered climate and fire regime (Chapin and Starfield 1997), the term has since been applied to a wide variety of ecosystems: mixed exoticnative tropical forests establishing on abandoned pasture and cropland in Puerto Rico (Lugo and Helmer 2004), nearshore ocean floors dominated by the exotic invasive alga Caulerpa (Davis et al. 1997), a grassland in Colorado (USA) composed of a unique assemblage of grass species planted by managers to restore an abandoned gravel pit (Seastedt et al. 2008), urban regions with heavily altered abiotic conditions and large numbers of exotic species (Kowarik 2011), and many others (Lindenmayer et al. 2008, Hobbs et al. 2009). The widespread interest in the topic has led to a comprehensive book (Hobbs et al. 2013) that explores the concept in much greater detail than we can explore. Despite the wealth of information and insightful analysis in that book, a broadly applicable definition is still lacking.
The definition in Hobbs et al. (2013:58) was updated from previous definitions to the following:

a system of abiotic, biotic and social components (and their interactions) that, by virtue of human influence, differ from those that prevailed historically, having a tendency to self-organize and manifest novel qualities without intensive human management. Novel ecosystems are distinguished from hybrid ecosystems by practical limitation (a combination of ecological, environmental and social thresholds) on the recovery of historical qualities.

Because the novel ecosystem concept is applied to more systems, we believe that this definition is insufficient. Under this definition, the tropical agroforestry plantation that Hobbs et al. (2006) reference (Ewel 1999) does not qualify as a novel ecosystem because researchers selected the species and managed the system. However, how does one define "intensive human management"? Similarly, should indirect anthropogenic stresses such as climate change, non-point-source pollution, and acid deposition be considered as human influence, even if their effects are universal? We argue that, for the concept to be useful to scientists, managers, and policy makers, the novel ecosystem must be defined in a more selective way that distinguishes it from other types of humanaltered ecosystems.

We propose the following definition:

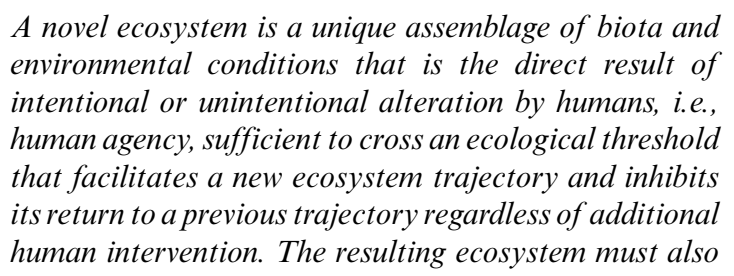

Erratum: The formatting of this manuscript was altered after publication. The adjusted format was published on 28 April 2014.

${ }^{1}$ Department of Natural Resources and the Environment, University of New Hampshire, ${ }^{2}$ Earth Systems Research Center, Institute for the Study of Earth, Oceans and Space, University of New Hampshire 
be self-sustaining in terms of species composition, structure, biogeochemistry, and ecosystem services. A defining characteristic of a novel ecosystem is a change in species composition relative to ecosystems present in the same biome prior to crossing a threshold.

Our definition is built on concepts that themselves need further clarification. Definitions clarifies our use of the terms human agency, thresholds, species composition, and self-sustaining. We apply this stricter definition of the novel ecosystem to numerous examples of ecosystems previously classified as novel in the literature and apply a designation (Table 1). We also give a detailed case study of a novel ecosystem (Box 2).

\section{DEFINITIONS}

\section{Human agency}

Human agency, i.e., the direct alteration of ecosystem characteristics by humans, whether intentional or unintentional, is the essential element in creating novel ecosystems and is central to our definition and those proposed earlier (Hobbs et al. 2006, 2013). Though many ecosystems also exhibit altered ecosystem functions and services because of direct human impact (Lugo and Helmer 2004), for an ecosystem to be considered novel, the change in ecosystem trajectory, i.e., change over time, must be initiated by direct human agency that is geographically situated in that ecosystem, e.g., species introduction, land-use management, or point-source pollution.

We hold that indirect anthropogenic stresses, e.g., climate change, nitrogen deposition, or ocean acidification, and natural variability, e.g., weather, seasons, or stochastic events, should not be considered drivers of novel ecosystem formation. These indirect global drivers affect the trajectories of all ecosystems on Earth, but often direct, local drivers overshadow global stresses at the scales at which ecosystems are managed and regulated. Thus, we deem the concept of human agency to be useful only insofar as it allows us to distinguish novel ecosystems from other types of ecosystems so that we may inform our management of them.

Direct anthropogenic alteration can be either deliberate or inadvertent. We use the term "designed" to denote an ecosystem created by intentional physical alteration aiming to enhance select ecosystem services, for example, a dammed river or cultivated land. These intentional human agencies may lead to unintentional changes within the newly designed ecosystem. However, designed ecosystems are heavily managed systems in which structure and function are largely the result of intentional human modification, which could include ecosystems that have been restored (Kueffer and Daehler 2009). In contrast, we use the term "impacted" to denote an ecosystem that results from unintentional alterations or degradation, for example, areas that receive wastewater effluent (Box 1). In impacted ecosystems, human actions have unintentionally altered the structure and function from the natural state, but a threshold (Fig. 1) has not been crossed. Impacted and designed ecosystems have the potential to become novel ecosystems if a threshold is crossed.

\section{Thresholds}

The second criterion of a novel ecosystem is that the system has crossed one or more thresholds. By a threshold, we mean a point along an ecosystem's trajectory at which a change in ecosystem properties becomes difficult or impossible to reverse, distinguishing a novel ecosystem from its previous state (Scheffer and Carpenter 2003, Groffman et al. 2006). Thresholds can be either biotic or abiotic in nature (Hobbs et al. 2006). A common biotic threshold involves the introduction of nonnative invasive species (Suding and Hobbs 2009). Once such species establish, they are often virtually impossible to eradicate without regular human management (Vitousek et al. 1997), and impacts on the ecosystem may linger even if eradication is successful (Hobbs et al. 2006). However, it is important to note that a change in species composition is a symptom, or "passenger," of changes in community-level properties such as colonization, competition, and mortality, not a threshold in and of itself (MacDougall and Turkington 2005).

Fig. 1. The middle trajectory represents a self-sustaining natural succession, where the upper and lower boundaries of the gray box represent natural variability. The dashed line represents an act of human agency triggering a threshold crossing that alters the successional trajectory of the ecosystem, resulting in a novel ecosystem in the case of the upper trajectory and an impacted or designed ecosystem in the case of the lower trajectory. Point A represents the removal of human agency, causing the ecosystem to revert back to its prior trajectory as is the case in designed or impacted ecosystems. Alternatively, the removal of human agency could result in a novel ecosystem if that ecosystem can become self-sustaining. Point B is the point at which the novel ecosystem reaches a self-sustaining state that continues on a trajectory that will not realign with its previous trajectory.

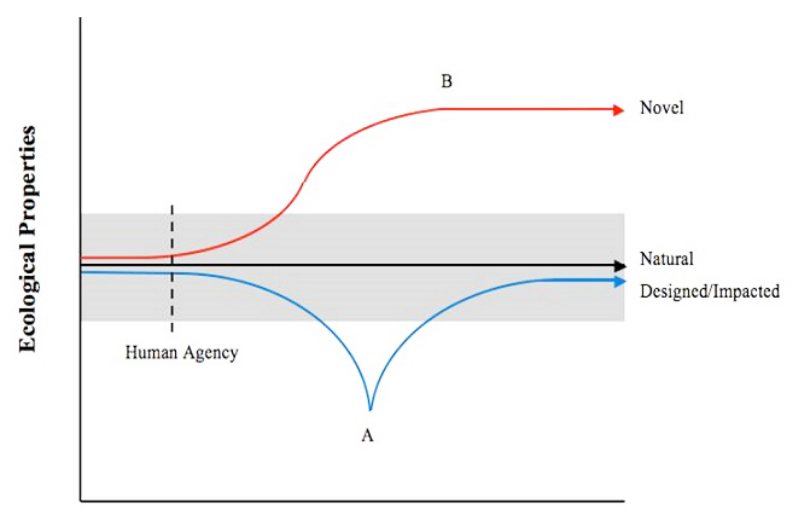

Time

Abiotic thresholds relate to ecosystem processes such as nutrient cycling, material import and export, and changes to the substrate. An ecological change that can serve as a threshold between a previous state and a novel ecosystem for one type of ecosystem may not produce a novel ecosystem in other ecological settings (Hobbs et al. 2009).

A defining feature of a threshold is that the ecosystem sustains itself in its new post-threshold state without human assistance (Hobbs et al. 2009). Positive feedbacks inherent in a novel ecosystem are one means by which a threshold can prevent the 
return to a previous state (Suding and Hobbs 2009). To verify that an ecosystem has crossed a threshold, a measurable difference must exist between the ecosystem's previous and current state. We propose that the occurrence of ecological parameters outside their historical ranges of variability (Walker and Meyers 2004, Keane et al. 2009) could be indicative of a threshold crossing, including, but not limited to the following: species composition, species diversity, salinity levels, $\mathrm{pH}$, productivity, decomposition rate, relative change in trophic level biomass, nutrient cycling rates, or distribution of a particular habitat element, either biotic or abiotic, in the ecosystem. As Suding and Hobbs (2009) acknowledge, research focused on determining such parameters that are prone to exhibiting threshold behavior will play a significant role in identifying novel ecosystem thresholds in future scenarios.

\section{Box 1:}

Human agency and ecosystem state change

Implicit in our analysis is the decision to view humans and human agency as external elements in a natural world. Although natural processes, such as succession, disturbance, and regeneration of communities (arrow 1), can affect ecosystems, humans alter global ecosystems in a number of different ways. This perspective of humans as external to the ecosystem allows us to categorize human interactions with natural environments as shown in Figure 2.

We differentiate human agency (solid arrows) into four forms. The first, arrow 2, depicts the transition to an impacted ecosystem through unintentional alteration or intentional degradation, e.g., pollution, introduction of invasive species, and failed management strategies; whereas arrow 3 represents the manipulation of ecosystem services for clear human gains, resulting in a designed ecosystem, e.g., agriculture, plantation forestry, and fish stocking. With additional human manipulation, e.g., remediation, impacted ecosystems can be made to provide additional ecosystem services, thereby transitioning to a designed system (arrow 4). Finally, arrow 5 embodies the transition of an altered ecosystem toward a more natural state. This can occur if no thresholds were crossed or through additional restoration efforts. Although this arrow completes the cycle of human impact, it is hard, if not impossible, to completely remove the human footprint from many ecosystems.

The dashed lines in the figure represent the removal of human agency. Lack of maintenance causes an ecosystem to change states from designed to impacted when the ecosystem's capacity to provide the ecosystem services it was designed to support diminishes (arrow 6). When unmaintained, a designed ecosystem may yield a novel system if a human-induced change causes ecological thresholds to be crossed and alters an ecosystem's trajectory (arrow 7). If left untreated by human agency, impacted systems may undergo further ecological change. If the trajectory of resulting succession based on these changes is distinctly different from that of the ecosystem's predecessor, a novel system can result (arrow 8).
Fig. 2. The role of human agency in the creation and maintenance of altered ecosystems. Arrows: (1) natural ecosystem processes, (2) unintentional alteration or intentional degradation, (3) altering ecosystem services for clear human gains, (4) environmental remediation, (5) ecosystem restoration, (6) lack of maintenance, and (7 and 8) novel succession.

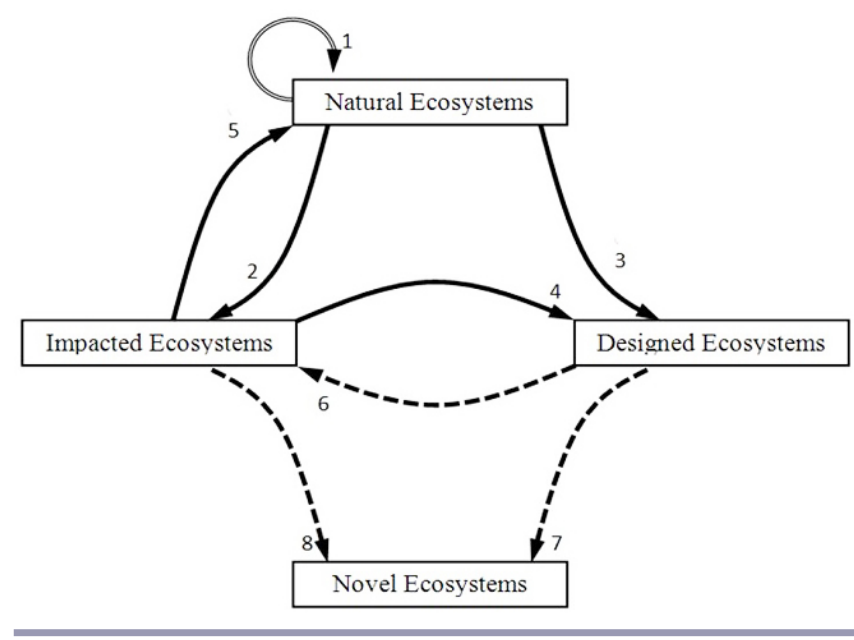

\section{Species composition}

The third criterion of a novel ecosystem is a unique species composition. New combinations of species and altered relative abundances can signify departure from a previous community. The never-before-seen species composition is a readily observable demonstration of what makes a novel ecosystem distinctive, regardless of whether individual species are the drivers or the passengers of change (MacDougall and Turkington 2005).

We consider a species composition to be unique if the combination of species and their relative abundances differ from all other ecosystems existing in the same biome. The establishment of invasive or nonnative species in ecosystems is the best-studied example of biophysical or biogeographical barriers being breached by human agency (Vitousek et al. 1997, Mooney and Hobbs 2000). Examples abound of invasive species as the drivers of change because aggressive, fast-growing organisms can often outcompete native species for resources (Callaway and Aschehoug 2000, Crowl et al.2008). Invasive species are also likely to take advantage of anthropogenic disturbances occurring within native ecosystems by gaining a foothold where native species are negatively affected by change (Dukes and Mooney 1999, McKinney and Lockwood 1999), thus acting as passengers of change. Regardless of the causal role played by invasive species, change in abiotic conditions typically accompanies a change in species composition (Chapin and Starfield 1997, Hooper et al. 2005).

\section{Self-sustaining}

The final criterion of a novel ecosystem is that its abiotic and biotic properties are self-sustaining, or able to remain and persist without, or in spite of, continued human intervention. All ecosystems, including novel ones, change because of natural 
Table 1. Examples of ecosystems that have been previously classified as novel in the literature. Each case study was designated as novel, designed, or impacted using the definition and four criteria outlined in this paper.

\begin{tabular}{|c|c|c|c|c|c|c|c|c|}
\hline \multicolumn{3}{|c|}{ Case Studies } & \multicolumn{5}{|c|}{ Novel Ecosystem Criteria } & \multirow[b]{2}{*}{ Comments } \\
\hline Ecosystem & Description & Reference & $\begin{array}{l}\text { Human } \\
\text { Agency } \\
(\mathrm{Y} / \mathrm{N}) \\
\end{array}$ & $\begin{array}{l}\text { Threshold } \\
(\mathrm{Y} / \mathrm{N})\end{array}$ & $\begin{array}{c}\text { Species } \\
\text { Composition } \\
(\mathrm{Y} / \mathrm{N}) \\
\end{array}$ & $\begin{array}{c}\text { Self- } \\
\text { Sustaining } \\
(\mathrm{Y} / \mathrm{N}) \\
\end{array}$ & $\begin{array}{c}\text { Novel/ } \\
\text { Designed/ } \\
\text { Impacted }\end{array}$ & \\
\hline $\begin{array}{l}\text { Puerto } \\
\text { Rico's 'new' } \\
\text { forests }\end{array}$ & $\begin{array}{l}\text { Regenerating forests on } \\
\text { degraded lands, composed } \\
\text { largely of non-native species } \\
\text { and exhibiting multiple } \\
\text { successional pathways }\end{array}$ & $\begin{array}{l}\text { Aide et al. } \\
\text { 2000, Lugo } \\
\text { and Helmer } \\
2004\end{array}$ & $\mathrm{Y}$ & $\mathrm{Y}$ & $\mathrm{Y}$ & $\mathrm{Y}$ & Novel & $\begin{array}{l}\text { The forests in this example } \\
\text { have altered soil } \\
\text { characteristics, nutrient } \\
\text { cycles, and rates of change in } \\
\text { the ecosystem. }\end{array}$ \\
\hline $\begin{array}{l}\text { Brazil's } \\
\text { tropical } \\
\text { savannas } \\
\text { (the } \\
\text { Cerrado) }\end{array}$ & $\begin{array}{l}\text { Savannas transformed } \\
\text { extensively by increased fire } \\
\text { and introduction of grass } \\
\text { species such as Melinis } \\
\text { minutiflora }\end{array}$ & $\begin{array}{l}\text { Hoffmann } \\
\text { and Jackson } \\
2000, \\
\text { Oliveria and } \\
\text { Marquis } \\
2002\end{array}$ & $\mathrm{Y}$ & $\mathrm{Y}$ & $\mathrm{Y}$ & $?$ & Designed & $\begin{array}{l}\text { It is not yet known what this } \\
\text { ecosystem would look like if } \\
\text { human control over fire } \\
\text { regime ceased. }\end{array}$ \\
\hline $\begin{array}{l}\text { Mediterranean } \\
\text { pine } \\
\text { woodlands }\end{array}$ & $\begin{array}{l}\text { Woodlands with altered } \\
\text { dynamics due to changing } \\
\text { climatic conditions coupled } \\
\text { with altitudinal range shifts } \\
\text { in herbivores }\end{array}$ & $\begin{array}{l}\text { Peñuelas et } \\
\text { al. } 2002 \text {, } \\
\text { Hódar et al. } \\
2003\end{array}$ & $\mathrm{~N}$ & $\mathrm{~N}$ & $\mathrm{Y}$ & $\mathrm{Y}$ & Impacted & $\begin{array}{l}\text { By definition, climate change } \\
\text { alone is insufficient as human } \\
\text { agency. }\end{array}$ \\
\hline $\begin{array}{l}\text { Rivers in the } \\
\text { western } \\
\text { United } \\
\text { States }\end{array}$ & $\begin{array}{l}\text { Rivers altered by regulation, } \\
\text { altered flows, and invasive } \\
\text { species }\end{array}$ & $\begin{array}{l}\text { Kowalewski } \\
\text { et al. } 2000 \text {, } \\
\text { Stromberg et } \\
\text { al. } 2007\end{array}$ & $\mathrm{Y}$ & $\mathrm{Y}$ & $\mathrm{Y}$ & $?$ & Designed & $\begin{array}{l}\text { Human management } \\
\text { continues because of } \\
\text { hydrologic controls. }\end{array}$ \\
\hline $\begin{array}{l}\text { Tropical } \\
\text { agroforestry } \\
\text { systems }\end{array}$ & $\begin{array}{l}\text { Diverse combinations of } \\
\text { native and non-native } \\
\text { perennial plants used locally } \\
\text { to derive ecosystem goods } \\
\text { and services }\end{array}$ & Ewel 1999 & $\mathrm{Y}$ & $\mathrm{Y}$ & $\mathrm{Y}$ & $\mathrm{N}$ & Designed & $\begin{array}{l}\text { Human management } \\
\text { continues to maximize } \\
\text { valuable ecosystem services. } \\
\text { The plantations would not } \\
\text { maintain current structure } \\
\text { and function without human } \\
\text { intervention. }\end{array}$ \\
\hline Kelp forests & $\begin{array}{l}\text { Removal of keystone species } \\
\text { (sea otter) results in shift to } \\
\text { novel ecosystem state }\end{array}$ & $\begin{array}{l}\text { Simenstad et } \\
\text { al. } 1978, \\
\text { Estes and } \\
\text { Duggins } \\
1995\end{array}$ & $\mathrm{Y}$ & $\mathrm{N}$ & $\mathrm{Y}$ & $\mathrm{N}$ & Impacted & $\begin{array}{l}\text { Where sea otters have } \\
\text { naturally recolonized, urchin } \\
\text { and kelp populations have } \\
\text { shifted back to their typical } \\
\text { levels in the presence of sea } \\
\text { otters. }\end{array}$ \\
\hline $\begin{array}{l}\text { Nearshore } \\
\text { ocean floors } \\
\text { invaded by } \\
\text { Caulerpa }\end{array}$ & $\begin{array}{l}\text { Invasion by the alga } \\
\text { Caulerpa in the } \\
\text { Mediterranean and } \\
\text { elsewhere leads to a novel } \\
\text { ecosystem and monospecific } \\
\text { dominance. }\end{array}$ & $\begin{array}{l}\text { Davis et al. } \\
1997, \\
\text { Meinesz } \\
1999\end{array}$ & $\mathrm{Y}$ & $?$ & $\mathrm{X}$ & $?$ & Impacted & $\begin{array}{l}\text { Data do not exist to show the } \\
\text { system has crossed a } \\
\text { threshold and is self- } \\
\text { sustaining }\end{array}$ \\
\hline $\begin{array}{l}\text { San } \\
\text { Francisco } \\
\text { Bay }\end{array}$ & $\begin{array}{l}\text { An estuary now dominated } \\
\text { almost entirely by non-native } \\
\text { species, with entirely novel } \\
\text { species combinations }\end{array}$ & $\begin{array}{l}\text { Cohen and } \\
\text { Carlton } \\
1998\end{array}$ & $?$ & $\mathrm{~N}$ & $\mathrm{Y}$ & $\mathrm{N}$ & Impacted & $\begin{array}{l}\text { Low resistance of native } \\
\text { biota, natural disturbance, } \\
\text { and human transport vectors, } \\
\text { or some combination of these } \\
\text { factors, have produced the } \\
\text { current ecosystem. }\end{array}$ \\
\hline $\begin{array}{l}\text { Field } \\
\text { Boundary } \\
\text { Stonewalls }\end{array}$ & $\begin{array}{l}\text { Long-standing } \\
\text { anthropogenic structures } \\
\text { found within and transiting } \\
\text { forested, agricultural, and } \\
\text { urban environments }\end{array}$ & $\begin{array}{l}\text { Francis } \\
2011 \text {, Collier } \\
2013\end{array}$ & $\mathrm{Y}$ & $?$ & Y & $\mathrm{Y}$ & Novel (?) & $\begin{array}{l}\text { Although this example could } \\
\text { represent a novel ecosystem, } \\
\text { further research to assess } \\
\text { ecosystem impact across } \\
\text { scales is needed. }\end{array}$ \\
\hline $\begin{array}{l}\text { Hawaiian } \\
\text { Forests }\end{array}$ & $\begin{array}{l}\text { Novel forests dominated by } \\
\text { introduced species maintain } \\
\text { ecosystem services after } \\
\text { decline of native tree species }\end{array}$ & $\begin{array}{l}\text { Mascaro et } \\
\text { al. } 2012\end{array}$ & $\mathrm{Y}$ & $\mathrm{Y}$ & $\mathrm{Y}$ & $\mathrm{Y}$ & Novel & $\begin{array}{l}\text { The new species composition } \\
\text { in these forests has affected } \\
\text { nutrient cycling and } \\
\text { ecosystem biomass. }\end{array}$ \\
\hline
\end{tabular}




\begin{tabular}{|c|c|c|c|c|c|c|c|c|}
\hline $\begin{array}{l}\text { Freshwater } \\
\text { Lakes, } \\
\text { Rivers, and } \\
\text { Ponds }\end{array}$ & $\begin{array}{l}\text { Invasion by non-native } \\
\text { species (e.g., suspension- } \\
\text { feeding bivalves, crustaceans, } \\
\text { and fish), stocking and } \\
\text { accidental release of hybrid } \\
\text { and non-native species. }\end{array}$ & Strayer 2010 & $\mathrm{Y}$ & Y & $\mathrm{Y}$ & $\mathrm{Y}$ & Novel & $\begin{array}{l}\text { These novel communities } \\
\text { have altered biogeochemical } \\
\text { cycles, hydrology, and } \\
\text { physical characteristics (e.g., } \\
\text { water clarity, light } \\
\text { penetration, etc.) of the } \\
\text { ecosystems. }\end{array}$ \\
\hline Rangeland & $\begin{array}{l}\text { Management induced new } \\
\text { combinations of introduced } \\
\text { and native plant and animal } \\
\text { species }\end{array}$ & $\begin{array}{c}\text { Belnap et al. } \\
2012\end{array}$ & $\mathrm{Y}$ & $?$ & $\mathrm{Y}$ & $?$ & $\begin{array}{l}\text { Novel, } \\
\text { Designed, } \\
\text { or } \\
\text { Impacted }\end{array}$ & $\begin{array}{l}\text { This includes numerous } \\
\text { examples that could be } \\
\text { considered either novel, } \\
\text { designed, or degraded, } \\
\text { depending on the role of } \\
\text { human management and } \\
\text { whether the ecosystem is self- } \\
\text { sustaining. }\end{array}$ \\
\hline
\end{tabular}

processes, e.g., erosion, channel migration, climatic shifts, and so forth, given enough time, regardless of human involvement (Compton and Boone 2000, Corenblit et al. 2007). However, for the novel ecosystem concept to be useful, we judge ecosystem stability on timescales relevant to the dominant biota and management practices of a given ecosystem. Human intrusion has caused novel ecosystems to deviate from their natural trajectories and cross thresholds, which prevent the return to historical ranges of variability in the relevant future. Thus, managers must choose a timescale by which to judge whether an ecosystem is novel. Choosing too long a timescale will cause confusion with natural succession and ecosystem turnover (Steiger and Corenblit 2012), whereas choosing too short a timescale will cause confusion with seasonality, population/ community dynamics, and random variation (Levin 1992). We propose a guideline of 10 - to 100 -year timescales, which is generally appropriate for most ecosystems, but care should be taken to select the proper timescale for a particular ecosystem.

\section{NOVEL ECOSYSTEMS IN THE ANTHROPOCENE}

\section{Global change and human influence}

As we enter the Anthropocene, humans continue to manipulate the biosphere with increasing intensity across all scales to sustain human population growth and meet demands for natural resources (Vitousek et al. 1997, Foley et al. 2005). In turn, degraded ecosystems are becoming more globally prevalent, encompassing more of the Earth's surface (Ellis et al. 2010). Global rates of ecosystem conversion are rising as natural ecosystems are converted into designed ecosystems, designed ecosystems are abandoned, and environmental degradation continues to produce impacted ecosystems. Human drivers allow for existing novel ecosystems to expand their global footprint and for the creation of additional novel ecosystems from degraded systems. Providing a conceptual framework (Figs. 1 and 2) to better define and identify novel ecosystems will help resource managers, government officials, scientists, political leaders, and citizens to better understand the complex problems associated with ecological management, restoration, and abatement in the new reality of the Anthropocene.
Box 2:

Novel ecosystem case study: abandoned shrimp ponds and mangroves in Thailand

An abandoned shrimp aquaculture site in Thailand (Matsui et al. 2012) meets our definition of a novel ecosystem. Originally a mangrove forest, the site was converted into a commercial shrimp pond and then abandoned in the 1980s. After abandonment, water flows deposited effluent from nearby shrimp ponds and offshore sediment within the raised walls of the pond, resulting in a drastic increase in soil elevation and reduction in the duration of tidal inundation, causing the soil to become dry and saline. Vegetation that could tolerate these conditions colonized the pond and included 2 succulent plants and a pioneer mangrove species, Avicennia marina. Carbon inputs were reduced as tidal water containing nearby shrimp pond effluent and offshore sediment reached the pond less frequently. Existing carbon stocks that were present readily decomposed in the resulting oxic conditions.

In 2001, Matsui et al. experimentally cleared the vegetation from the abandoned shrimp farm and planted seedlings of local mangroves (Bruguiera cylindrica and Rhizophora mucronata). They monitored the site for species composition, soil organic carbon, and total carbon over a 10 -year period. The authors found that the planted mangrove species had low survival rates (Fig. 3), and those trees that survived had a much slower growth rate when compared to growth rates in favorable tidal conditions. These favorable conditions were achieved by excavating a portion of the site to restore its hydrology. Over the course of 10 years, the 2 local mangrove species (B. cylindrica and $R$. mucronata) grew about twice as tall in restored tidal conditions compared to the drier conditions of the abandoned shrimp pond, indicating inhibited growth in the absence of tidal restoration. Soon after planting the local mangroves in the unrestored shrimp ponds, the area was recolonized with the drought-tolerant mangrove ( $A$. marina), which accounted for more than $90 \%$ of the standing biomass and outcompeted the 2 native mangroves. Soil organic carbon decreased over the study period (Fig. 3), and Matsui et al. (2012) expect this trend to continue because of accelerated decomposition during dry periods. 
We classify this abandoned shrimp pond as a novel ecosystem because it satisfies each of the four criteria that we describe as defining a novel ecosystem. Deforestation, obstruction of tidal influence, and soil accumulation from effluent are human agencies by which this ecosystem was created. The species composition present before the restoration attempt was significantly different from that of the adjacent natural mangrove forests. Even after planting local mangrove species, the system reverted back to the drought-resistant halophytic plant community dominated by $A$. marina. Even if the hydrology of the area were restored, shrimp ponds might reaccumulate sediment, requiring continued maintenance to resist developing novel conditions. Mangrove restoration efforts that do not restore tidal conditions have been unsuccessful in the past (Elster 2000, Matsui et al. 2010) because of the crossing of abiotic thresholds in soil conditions and an altered hydroperiod. The resilience of this new community provides further evidence that the system has crossed a threshold and that the new system is self-sustaining.

Fig. 3. The survival rate of 2 mangrove species, Rhizophora mucronata and Bruguiera cylindrica, from 5 months to 10 years after planting. Soil organic carbon (tC/ha) of the excavated and unexcavated area illustrates a decline in carbon in the excavated area (Matsui et al. 2012). Note that the initial increase is likely due to incorporation into the soil of the unsuccessful planted mangroves.

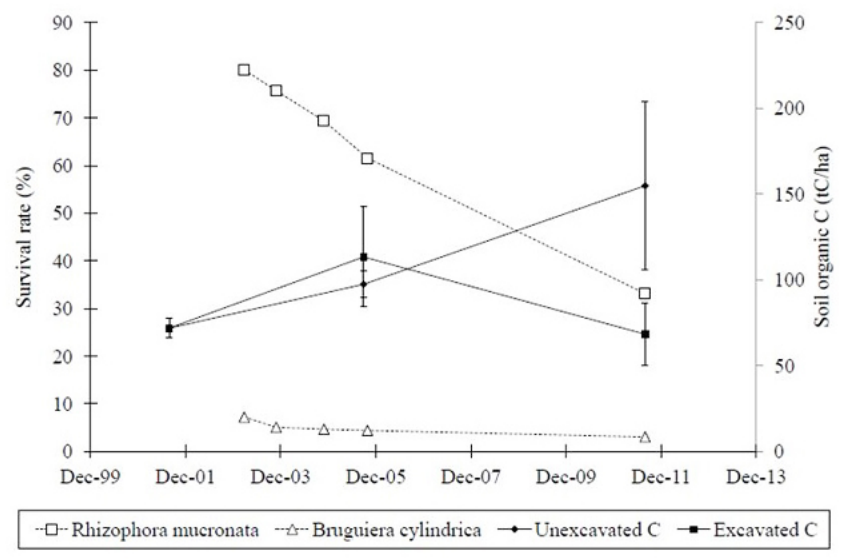

\section{Excluding indirect anthropogenic stresses}

Perhaps the greatest difference between our definition of novel ecosystems and previous definitions is the exclusion of large-scale, i.e., global and regional, indirect anthropogenic impacts such as climate change, ocean acidification, and nitrogen deposition. We argue that by excluding these types of large-scale changes, the novel ecosystem concept is more useful. Specifically, if a system can only be classified as novel or not novel and an entire landscape is considered novel, there is no way to distinguish between areas impacted by large- or small-scale stressors.

Understanding the scale of impact is vital to properly manage novel ecosystems. For example, coral reefs are in danger globally because of a range of anthropogenic impacts that are evident at both global and local scales. Using the more inclusive definition of Hobbs et al. (2013), nearly all coral reef ecosystems would be considered novel because of ocean acidification and global climate change (Pandolfi et al. 2011). Alternatively, using our more restrictive definition, only a subset of coral reefs would be classified as novel, i.e., those that have been impacted by local stressors like overfishing, infectious disease, invasive species, or algal blooms (Mumby and Steneck 2008, Hobbs et al. 2013). With a smaller subset of coral reef ecosystems, ecosystem managers could more appropriately target areas for establishment of marine reserves, fisheries management, restoration, or other local solutions. We argue that by restricting the definition, understanding whether a system is novel or not will be more useful for the people directly involved in the protection, management, and/or use of the ecosystems.

\section{Valuing novel ecosystems properly}

Identification of novel ecosystems is also vital for proper ecosystem assessment and management. The framework we have developed recognizes that novel ecosystems are not inherently good or bad, but that human actions are creating more of them. The identification of novel ecosystems is an important triage tool when deciding how to allocate resources for ecosystem restoration. Managers may best allocate restoration resources to natural, impacted, or designed ecosystems that have yet to cross ecological thresholds rather than to novel ecosystems. Although further research is needed, the novel ecosystem concept suggests that societies will most efficiently invest time, effort, and financial resources if they focus on managing novel ecosystems for the ecosystem services that they can provide, rather than attempting to restore them to their previous states. In this light, managers should measure the health and function of novel ecosystems against standards that reflect their novel properties rather than standards that reflect the properties of their prenovel precedents.

Although many studies document the harmful effects of invasive species on ecosystem services (Mooney and Cleland 2001, Pejchar and Mooney 2009), novel ecosystems that include invasive species have been shown to facilitate the regrowth of native species and to enhance ecosystem services from impacted or designed states (Lugo and Helmer 2004). Threshold crossings often alter species composition by destroying native seed banks or by changing the abiotic attributes of ecosystems such that regeneration of native pioneer species is unsuccessful. However, nonnative species can also build soils, alter hydrology, and provide structure and habitat for native species. This may facilitate the creation of a selfsustaining novel ecosystem. Managers should seek to better understand and evaluate the trade-offs and potential benefits that novel ecosystems and nonnative species can create in the longterm function of ecosystems and the services they provide.

Future research on novel ecosystems should build knowledge surrounding the trends that signal threshold crossings. To prevent the loss of highly valued but degraded ecosystems, managers must anticipate threshold crossings. By recognizing the trends that have been observed after a particular human agency has been removed, managers can make informed decisions regarding ecosystem trajectories rather than allowing managed ecosystems to develop into unfamiliar and undesirable systems after abandonment. 


\section{The novel outlook}

Novel ecosystems present a unique opportunity to further our understanding of many fundamental and emerging concepts in ecology. Although fundamental research on pristine ecosystems is still important, novel ecosystems should be studied for their growing contribution to the Earth system and their inherent effects on underlying ecological characteristics such as resilience, competition, extinction, and speciation. The continued formation of novel ecosystems offers new opportunities for further insights into threshold dynamics, ecosystem structure, and longevity.

For example, in the creation of a novel ecosystem, the crossing of a threshold signals that human agency has exceeded the resilience of some aspect of the previous ecosystem. By definition, the changes in ecosystem attributes that are associated with a crossed threshold are irreversible. However, after crossing a threshold, it is unclear whether the resulting ecosystem will be more or less resistant to further change. Does this resistance equally extend to both natural and anthropogenic disturbance? Current research on the relation of resilience to regime shifts, thresholds, and nonlinearity in ecosystems is exploring these concepts (e.g., Folke et al. 2004, Sundstrom et al. 2012). Consequently, we propose that novel ecosystems are ideal laboratories for addressing many current ecological questions.

\section{A case for ecosystem monitoring}

One specific hurdle in identifying and defining novel ecosystems continues to be the interaction between the timescale of ecosystem change and the amount of monitoring needed relative to such changes. In the same way that ecosystems can be defined at spatial scales ranging from microscopic to global, timescales for the formation and turnover of novel ecosystems can also vary widely. The high variability in individual life spans, biological processes, abiotic/biotic interactions, ecosystem function, and drivers of ecological change makes it impossible to set uniform limits for a timescale appropriate for all novel ecosystems. Most of the examples we present were on a decadal timescale; however, it is not hard to imagine novel ecosystems forming at both ends of the temporal spectrum. For example, novel microbial ecosystems could form at rapid timescales in response to environmental change because of short generation times, e.g., bacterial populations that have formed to subsist on plastic waste in the open ocean (Dickey Zaikab 2011). At the other end of the continuum, for ecosystems dominated by long-lived individuals, such as redwood forests, novel ecosystem formation could require hundreds or thousands of years. At these longer timescales, drivers of natural ecological change, e.g., evolution and geologic processes, may have a greater influence on ecosystem changes, and the role of human agents may be diminished. Overall, managers should evaluate novel ecosystems on a case-by-case basis because of variations in the time they require to respond to acts of human agency and variations in how these responses can be measured.

Both short and long timescales present unique challenges to understanding novel ecosystems. At longer timescales, isolating the influence of individual, anthropogenic disturbances necessary for the formation of a novel ecosystem is difficult and also requires long-term ecosystem monitoring. In our review of the literature, we found that portions of the coastline of the Mediterranean Sea invaded by Caulerpa are one example of impacted systems that seem to have the potential to become novel ecosystems given enough time, but that either insufficient time or information exists to clearly designate them as novel (Table 1). This lack of data is pervasive and illustrates the need for comprehensive, long-term ecological monitoring to develop an accurate understanding of these systems and their trajectories. Conversely, ecosystem turnover in response to rapid ecological change at shorter timescales could result in the designation of a series of novel ecosystems where in actuality the original ecosystem is still in flux and has not yet become self-sustaining. Isolating and studying a single novel ecosystem may be difficult if drivers exist that promote continuous ecosystem change, resulting in an unstable trajectory. The duration of monitoring needs to be appropriate for the system under study for the data collected to fully depict the influence of human agency and the ecosystem's response over time. As such, future studies should be of sufficient duration to capture ecosystem changes across multiple generations of the dominant biota and to address changes in stocks and flows of energy and key nutrients to identify suspected thresholds.

\section{CONCLUSION}

By narrowing the definition of a novel ecosystem, it is now possible to better apply the concept to human-influenced ecosystems globally. Understanding that these ecosystems are not merely degraded but rather entirely different from those that existed previously is fundamental to ecosystem management across all scales and biomes. This insight will encourage human societies to study and manage novel ecosystems as functioning ecosystems, with an eye toward their novel ecology and ecosystem services. Viewing novel ecosystems in this way and recognizing the trade-offs between their positive and negative aspects will allow managers the pragmatic flexibility needed to make informed and sensible decisions concerning resource use and ecosystem maintenance.

Responses to this article can be read online at: http://www.ecologyandsociety.org/issues/responses. php/6192

\section{Acknowledgments:}

This manuscript was the product of the Fall 2012 "Hot Topics in Ecosystem Ecology" seminar course offered by the University of New Hampshire, Department of Natural Resources and the Environment. N. B. Morse was funded by the National Science Foundation (NSF-OCE-1238212). Additional support was provided by the UNH College of Life Sciences and Agriculture. The authors appreciate early comments by Drs. Heidi Asbjornsen, David Burdick, Thomas Lee, and Richard Smith and two anonymous reviewers, which improved the manuscript.

\section{LITERATURE CITED}

Aide, T. M., J. K. Zimmerman, J. B. Pascarella, L. Rivera, and H. Marcano-Vega. 2000. Forest regeneration in a chronosequence of tropical abandoned pastures: implications for restoration ecology. Restoration Ecology 8:328-338. 
Belnap, J., J. A. Ludwig, B. P. Wilcox, J. L. Betancourt, W. R. J. Dean, B. D. Hoffmann, and S. J. Milton. 2012. Introduced and invasive species in novel rangeland ecosystems: friends or foes? Rangeland Ecology \& Management 65:569-578. http://dx.doi. org/10.2111/REM-D-11-00157.1

Callaway, R. M., and E. T. Aschehoug. 2000. Invasive plants versus their new and old neighbors: a mechanism for exotic invasion. Science 290:521-523. http://dx.doi.org/10.1126/ science.290.5491.521

Chapin, F. S., III, and A. M. Starfield. 1997. Time lags and novel ecosystems in response to transient climatic change in arctic Alaska. Climatic Change 35:449-461. http://dx.doi.org/10.1023/ A:1005337705025

Cohen, A. N., and J. T. Carlton. 1998. Accelerating invasion rate in a highly invaded estuary. Science 279:555-558. http://dx.doi. org/10.1126/science. 279.5350 .555

Collier, M. J. 2013. Field boundary stone walls as exemplars of 'novel' ecosystems. Landscape Research 38:141-150.

Compton, J. E., and R. D. Boone. 2000. Long-term impacts of agriculture on soil carbon and nitrogen in New England forests. Ecology 81:2314-2330. http://dx.doi.org/10.1890/0012-9658(2000) 081[2314:LTIOAO]2.0.CO;2

Corenblit, D., E. Tabacchi, J. Steiger, and A. M. Gurnell. 2007. Reciprocal interactions and adjustments between fluvial landforms and vegetation dynamics in river corridors: a review of complementary approaches. Earth-Science Reviews 84:56-86. http://dx.doi.org/10.1016/j.earscirev.2007.05.004

Crowl, T. A., T. O. Crist, R. R. Parmenter, G. Belovsky, and A. E. Lugo. 2008. The spread of invasive species and infectious disease as drivers of ecosystem change. Frontiers in Ecology and the Environment 6:238-246. http://dx.doi.org/10.1890/070151

Davis, A. R., D. E. Roberts, and S. P. Cummins. 1997. Rapid invasion of a sponge-dominated deep-reef by Caulerpa scalpelliformis (Chlorophyta) in Botany Bay, New South Wales. Australian Journal of Ecology 22:146-150. http://dx.doi. org/10.1111/j.1442-9993.1997.tb00653.x

Dickey Zaikab, G. 2011. Marine microbes digest plastic. Nature News. http://dx.doi.org/10.1038/news.2011.191

Dukes, J. S., and H. A. Mooney. 1999. Does global change increase the success of biological invaders? Trends in Ecology \& Evolution 14:135-139. http://dx.doi.org/10.1016/S0169-5347(98)01554-7

Ellis, E. C., K. Klein Goldewijk, S. Siebert, D. Lightman, and N. Ramankutty. 2010. Anthropogenic transformation of the biomes, 1700 to 2000. Global Ecology and Biogeography 19:589-606.

Elster, C. 2000. Reasons for reforestation success and failure with three mangrove species in Colombia. Forest Ecology and Management 131:201-214. http://dx.doi.org/10.1016/S0378-1127 (99)00214-5

Estes, J. A., and D. O. Duggins. 1995. Sea otters and kelp forests in Alaska: generality and variation in a community ecological paradigm. Ecological Monographs 65:75-100. http://dx.doi. $\underline{\text { org } / 10.2307 / 2937159}$
Ewel, J. J. 1999. Natural systems as models for the design of sustainable systems of land use. Agroforestry Systems 45:1-21. http://dx.doi.org/10.1023/A:1006219721151

Foley, J. A., R. DeFries, G. P. Asner, C. Barford, G. Bonan, S. R. Carpenter, F. S. Chapin, M. T. Coe, G. C. Daily, H. K. Gibbs, J. H. Helkowski, T. Holloway, E. A. Howard, C. J. Kucharik, C. Monfreda, J. A. Patz, I. C. Prentice, N. Ramankutty, and P. K. Snyder. 2005. Global consequences of land use. Science 309:570-574. http://dx.doi.org/10.1126/science.1111772

Folke, C., S. Carpenter, B. Walker, M. Scheffer, T. Elmqvist, L. Gunderson, and C. S. Holling. 2004. Regime shifts, resilience, and biodiversity in ecosystem management. Annual Review of Ecology, Evolution, and Systematics 35:557-581. http://dx.doi. org/10.1146/annurev.ecolsys.35.021103.105711

Francis, R. A. 2011. Wall ecology: a frontier for urban biodiversity and ecological engineering. Progress in Physical Geography 35:43-63. http://dx.doi.org/10.1177/0309133310385166

Groffman, P. M., J. S. Baron, T. Blett, A. J. Gold, I. Goodman, L. H. Gunderson, B. M. Levinson, M. A. Palmer, H. W. Paerl, and G. D. Peterson. 2006. Ecological thresholds: the key to successful environmental management or an important concept with no practical application? Ecosystems 9:1-13. http://dx.doi. org/10.1007/s10021-003-0142-Z

Hobbs, R. J., S. Arico, J. Aronson, J. S. Baron, P. Bridgewater, V. A. Cramer, P. R. Epstein, J. J. Ewel, C. A. Klink, A. E. Lugo, D. Norton, D. Ojima, D. M. Richardson, E. W. Sanderson, F. Valladares, M. Vilà, R. Zamora, and M. Zobel. 2006. Novel ecosystems: theoretical and management aspects of the new ecological world order. Global Ecology and Biogeography 15:1-7. http://dx.doi.org/10.1111/j.1466-822X.2006.00212.x

Hobbs, R. J., E. S. Higgs, and C. M. Hall, editors. 2013. Novel ecosystems: intervening in the new ecological world order. John Wiley \& Sons, Chichester, UK. http://dx.doi.org/10.1002/9781118354186

Hobbs, R. J., E. Higgs, and J. A. Harris. 2009. Novel ecosystems: implications for conservation and restoration. Trends in Ecology \& Evolution 24:599-605. http://dx.doi.org/10.1016/j.tree.2009.05.012

Hódar, J. A., J. Castro, and R. Zamora. 2003. Pine processionary caterpillar Thaumetopoea pityocampa as a new threat for relict Mediterranean Scots pine forests under climatic warming. Biological Conservation 110:123-129. http://dx.doi.org/10.1016/ $\underline{\text { S0006-3207(02)00183-0 }}$

Hoffmann, W. A., and R. B. Jackson. 2000. Vegetation-climate feedbacks in the conversion of tropical savanna to grassland. Journal of Climate 13:1593-1602. http://dx.doi.org/10.1175/1520-0442 (2000)013<1593:VCFITC>2.0.CO;2

Hooper, D. U., F. S. Chapin, III, J. J. Ewel, A. Hector, P. Inchausti, S. Lavorel, J. H. Lawton, D. M. Lodge, M. Loreau, S. Naeem, B. Schmid, H. Setälä, A. J. Symstad, J. Vandermeer, and D. A. Wardle. 2005. Effects of biodiversity on ecosystem functioning: a consensus of current knowledge. Ecological Monographs 75:3-35. http://dx.doi.org/10.1890/04-0922

Keane, R. E., P. F. Hessburg, P. B. Landres, and F. J. Swanson. 2009. The use of historical range and variability (HRV) in 
landscape management. Forest Ecology and Management 258:1025-1037. http://dx.doi.org/10.1016/j.foreco.2009.05.035

Kowalewski, M., G. E. A. Serrano, K. W. Flessa, and G. A. Goodfriend. 2000. Dead delta's former productivity: two trillion shells at the mouth of the Colorado River. Geology 28:1059-1062. http://dx.doi.org/10.1130/0091-7613(2000)28<1059:DDFPTT>2.0. $\mathrm{CO} ; 2$

Kowarik, I. 2011. Novel urban ecosystems, biodiversity, and conservation. Environmental Pollution 159:1974-1983. http://dx. doi.org/10.1016/j.envpol.2011.02.022

Kueffer, C., and C. C. Daehler. 2009. A habitat-classification framework and typology for understanding, valuing, and managing invasive species impacts. Pages 77-101 in Inderjit, editor. Management of invasive weeds. Springer, Dordrecht, The Netherlands.

Levin, S. 1992. The problem of pattern and scale in ecology: the Robert H. MacArthur award lecture. Ecology 73:1943-1967. http://dx.doi.org/10.2307/1941447

Lindenmayer, D. B., J. Fischer, A. Felton, M. Crane, D. Michael, C. Macgregor, R. Montague-Drake, A. Manning, and R. J. Hobbs. 2008. Novel ecosystems resulting from landscape transformation create dilemmas for modern conservation practice. Conservation Letters 1:129-135. http://dx.doi.org/10.1111/ j.1755-263X.2008.00021.X

Lugo, A. E., and E. Helmer. 2004. Emerging forests on abandoned land: Puerto Rico's new forests. Forest Ecology and Management 190:145-161. http://dx.doi.org/10.1016/j.foreco.2003.09.012

MacDougall, A. S., and R. Turkington. 2005. Are invasive species the drivers or passengers of change in degraded ecosystems? Ecology 86:42-55. http://dx.doi.org/10.1890/04-0669

Mascaro, J., R. F. Hughes, and S. A. Schnitzer. 2012. Novel forests maintain ecosystem processes after the decline of native tree species. Ecological Monographs 82:221-228. http://dx.doi. org/10.1890/11-1014.1

Matsui, N., K. Morimune, W. Meepol, and J. Chukwamdee. 2012. Ten year evaluation of carbon stock in mangrove plantation reforested from an abandoned shrimp pond. Forests 3:431-444. http://dx.doi.org/10.3390/f3020431

Matsui, N., J. Suekuni, M. Nogami, S. Havanond, and P. Salikul. 2010. Mangrove rehabilitation dynamics and soil organic carbon changes as a result of full hydraulic restoration and re-grading of a previously intensively managed shrimp pond. Wetlands Ecology and Management 18:233-242. http://dx.doi.org/10.1007/s11273-009-9162-6

McKinney, M. L., and J. L. Lockwood. 1999. Biotic homogenization: a few winners replacing many losers in the next mass extinction. Trends in Ecology \& Evolution 14:450-453. http:// dx.doi.org/10.1016/S0169-5347(99)01679-1

Meinesz, A. 1999. Killer algae. D. Simberloff, translator. First edition. University of Chicago Press, Chicago, Illinois, USA.

Mooney, H. A., and E. E. Cleland. 2001. The evolutionary impact of invasive species. Proceedings of the National Academy of Sciences of the United States of America 98:5446-5451. http://dx. doi.org/10.1073/pnas.091093398
Mooney, H. A., and R. J. Hobbs. 2000. Invasive species in a changing world. Island, Washington, D.C., USA.

Mumby, P. J., and R. S. Steneck. 2008. Coral reef management and conservation in light of rapidly evolving ecological paradigms. Trends in Ecology \& Evolution 23:555-563. http://dx. doi.org/10.1016/j.tree.2008.06.011 
Oliveria, P. S., and R. J. Marquis, editors. 2002. The cerrados of Brazil: ecology and natural history of a neotropical savanna. Columbia University Press, New York, New York, USA.

Pandolfi, J. M., S. R. Connolly, D. J. Marshall, and A. L. Cohen. 2011. Projecting coral reef futures under global warming and ocean acidification. Science 333:418-422. http://dx.doi. org/10.1126/science.1204794

Pejchar, L., and H. A. Mooney. 2009. Invasive species, ecosystem services and human well-being. Trends in Ecology \& Evolution 24:497-504. http://dx.doi.org/10.1016/j.tree.2009.03.016

Peñuelas, J., I. Filella, and P. Comas. 2002. Changed plant and animal life cycles from 1952 to 2000 in the Mediterranean region. Global Change Biology 8:531-544. http://dx.doi.org/10.1046/ j.1365-2486.2002.00489.x

Scheffer, M., and S. R. Carpenter. 2003. Catastrophic regime shifts in ecosystems: linking theory to observation. Trends in Ecology \& Evolution 18:648-656. http://dx.doi.org/10.1016/j. $\underline{\text { tree.2003.09.002 }}$

Seastedt, T. R., R. J. Hobbs, and K. N. Suding. 2008. Management of novel ecosystems: are novel approaches required? Frontiers in Ecology and the Environment 6:547-553. http://dx.doi. org/10.1890/070046

Simenstad, C. A., J. A. Estes, and K. W. Kenyon. 1978. Aleuts, sea otters, and alternate stable-state communities. Science 200:403-411. http://dx.doi.org/10.1126/science.200.4340.403

Steiger, J., and D. Corenblit. 2012. The emergence of an 'evolutionary geomorphology'? Central European Journal of Geosciences 4:376-382. http://dx.doi.org/10.2478/s13533-011-0075-6

Strayer, D. L. 2010. Alien species in fresh waters: ecological effects, interactions with other stressors, and prospects for the future. Freshwater Biology 55:152-174. http://dx.doi.org/10.1111/ j.1365-2427.2009.02380.x

Stromberg, J. C., S. J. Lite, R. Marler, C. Paradzick, P. B. Shafroth, D. Shorrock, J. M. White, and M. S. White. 2007. Altered streamflow regimes and invasive plant species: the Tamarix case. Global Ecology and Biogeography 16:381-393. http://dx.doi.org/10.1111/ j.1466-8238.2007.00297.x

Suding, K. N., and R. J. Hobbs. 2009. Threshold models in restoration and conservation: a developing framework. Trends in Ecology \& Evolution 24:271-279. http://dx.doi.org/10.1016/j. tree.2008.11.012

Sundstrom, S. M., C. R. Allen, and C. Barichievy. 2012. Species, functional groups, and thresholds in ecological resilience. Conservation Biology 26:305-314. http://dx.doi.org/10.1111/ j.1523-1739.2011.01822.X

Vitousek, P. M., H. A. Mooney, J. Lubchenco, and J. M. Melillo. 1997. Human domination of Earth's ecosystems. Science 277:494-499. http://dx.doi.org/10.1126/science.277.5325.494

Walker, B., and J. A. Meyers. 2004. Thresholds in ecological and social-ecological systems: a developing database. Ecology and Society 9(2): 3. [online] URL: http://www.ecologyandsociety.org/ vol9/iss $2 / \operatorname{art} 3 /$ 